\title{
MYCOFLORA ASSOCIATED WITH DECOMPOSITION OF RICE STUBBLE MIXED WITH SOIL
}

\author{
Vibha Pandey ${ }^{1}$, Asha Sinha ${ }^{2}$ \\ ${ }^{1}$ Department of Plant Pathology, Rajendra Agricultural University, \\ Pusa (Samastipur) Bihar - 848125, India \\ ${ }^{2}$ Department of Mycology \& Plant Pathology, Institute of Agricultural Sciences, \\ Banaras Hindu University, Varanasi-221005, India
}

Received: 29 July, 2007

Accepted: 03 June, 2008

\begin{abstract}
Fungi inhabiting rice stubble mixed with soil were isolated by dilution plate technique. Moisture content of decomposed rice stubble mixed with soil was $25.32 \%$ in the month of August and minimum (5.35\%) in the month of April and $\mathrm{pH}$ varied between 6.8-7.2. The highest $\left(47.68 \times 10^{4}\right)$ fungal population in $1 \mathrm{~g}$ of rice stubble mixed with soil was recorded in the month of October and the lowest $\left(16.88 \times 10^{4}\right)$ in the month of May. A total of twenty-nine fungal species were recorded during the entire period of decomposition. Dueteromycetous fungi constituted 75.86 per cent of total fungal population followed by zygomycetous, oomycetous and ascomycetous fungi. Monthly variation in fungal population was correlated with substrate availability and climatic factors. Dominance of Rhizopus stolonifer, Aspergillus flavus and Trichoderma harzianum was recorded during the decomposition while Pestalotia mangiferae, Torula graminis and Alternaria solani were obtained as rare fungal species.
\end{abstract}

Key words: decomposition, environmental conditions, rice stubble, succession

\section{INTRODUCTION}

Crop debris, a principal amendment applied to the soil system, play an important role in maintaining soil fertility and other physical properties of soil. Rice stubble is highly rich in cellulose and lignin, whose decomposition can help in improving soil health. The process of decomposition is a complex phenomenon and completed by multitude of organisms, where fungi play an important role, because they grow well under semi-solid fermentation conditions by virtue of their ability to ramify through solid substrate (Hudson 1971). The occurrence of primary fungal colonizers and successive invaders are governed by interacting factors of soil, crop residues, climatic

*Corresponding address:
vibha00@rediffmail.com 
factors, $\mathrm{pH}$, depth, aeration and organic nutrients (Williams and Gray 1974; Nikhra 1981; Singh 2001; Rai et al. 2001). The bacterial and fungal population increases as the amount of applied root residue increases in soil (Sameni and Pour 2001). The present investigation deals with the study of soil mycoflora colonizing rice stubble incorporated into the soil after harvesting the rice crop under prevailing environmental conditions.

\section{MATERIALS AND METHODS}

In order to study the decomposition of rice stubble incorporated into the soil by soil mycoflora, this material was mixed into the soil one week after harvest of rice at the experimental site. A trench, with an area of $4 \times 4 \times 1 \mathrm{~m}$ was dug and soil of ricewheat cropping system was used to fill it. The rice stubble was mixed into the soil of trench at a depth of 5-6 cm. Sampling programme was performed from October, 2001 to August, 2002 at monthly intervals. Different media like Czapek dox agar and potato dextrose agar medium were prepared for isolation and sub-culturing of fungi, respectively. The method used for the study of decomposing rice-stubble mixed with the soil by soil inhabiting mycoflora is discussed below.

\section{Dilution plate technique}

Warcup (1960) proposed this method for isolation and determination of fungal population. Stubble samples were powdered and one gram of powder was suspended in $10 \mathrm{ml}$ of sterilized distilled water and further dilution series $\left(1: 10^{3}, 1: 10^{4}, 1: 10^{5}\right)$ were prepared. Five replications with $1 \mathrm{ml}$ of each dilution were incubated on Czapek dox agar with $100 \mathrm{ppm}$ streptomycin at $25 \pm 2^{\circ} \mathrm{C}$ for a week and fungi were recorded at monthly intervals. Total number of fungi/g of oven-dried stubble was calculated with the help of the following formula:

Total no. of fungi $=\frac{\text { No. of fungi/g oven dried litter } \times \text { Concentration of the solution }}{\text { Oven dried weight of the litter }}$

\section{Determination of frequency and abundance of fungi}

Frequency and abundance of fungi were determined using the following formula (Saksena 1955):

$$
\begin{aligned}
& \text { Frequency }(\%)=\frac{\text { No. of occurrence of a species }}{\text { Total no. of Petridishes }} \times 100 \\
& \text { Abundance }=\frac{\text { Total no. of colonies of a species }}{\text { Number of plates with fungal colonies }}
\end{aligned}
$$

The frequency values were further classified into five frequency classes as shown below:

Class 1: Species occurring in 1-20\% of Petri dishes

Class 2: Species occurring in $21-40 \%$ of Petri dishes

Class 3: Species occurring in $41-60 \%$ of Petri dishes 
Class 4: Species occurring in $61-80 \%$ of Petri dishes

Class 5: Species occurring in $81-100 \%$ of Petri dishes

Only class values of frequency and absolute values of abundance are given in the nearest whole numbers and not in fractions in the tables.

The fungal species were identified with the help of available literature (Thom and Raper 1945; Ellis 1971; Barnett and Hunter 1972). Moisture content was determined by drying the sample at $60^{\circ} \mathrm{C}$ for $24 \mathrm{~h}$ and subtracting this value from initial weight of the respective sample value, $\mathrm{pH}$ of rice stubble was determined using the Elico-Electric $\mathrm{pH}$ meter. Meteorological data (Fig. 1) showing maximum and minimum temperature, relative humidity and rainfall was obtained from Department of Agronomy, Institute of Agricultural Sciences, Banaras Hindu University.

\section{RESULTS}

Variation observed in the number of fungi per gram of stubble mixed with the soil, $\mathrm{pH}$ and moisture content are presented in Table 1. In the present study, the maximum $(25.32 \%)$ moisture content was recorded in the month of August and minimum (5.35\%) in the month of April. The $\mathrm{pH}$ varied from 6.8 to 7.2 with no definite trend. The maximum fungal population $\left(47.68 \times 10^{4} / \mathrm{g}\right)$ was recorded in the month of October and minimum $\left(16.88 \times 10^{4} / \mathrm{g}\right)$ in the month of May. Moisture content varied throughout the decomposition period. During the rainy seasons, moisture content increased which supported more fungal population on rice stubble while in summer months low moisture content gave less opportunity to fungi to grow.

Table 1. Monthly meteorological data of Varanasi during 2001-2002

\begin{tabular}{|c|c|c|c|c|c|}
\hline \multirow{2}{*}{ Months } & \multirow{2}{*}{$\begin{array}{c}\text { Rainfall } \\
\text { [mm] }\end{array}$} & \multicolumn{2}{|c|}{ Temperature $\left[{ }^{\circ} \mathrm{C}\right]$} & \multicolumn{2}{|c|}{ Relative humidity [\%] } \\
\hline & & $\max$. & $\min$. & $\max$. & $\min$. \\
\hline \multicolumn{6}{|c|}{2001} \\
\hline October & 28.4 & 32.2 & 21.7 & 85.0 & 61.4 \\
\hline November & 0.0 & 29.1 & 15.0 & 83.5 & 40.0 \\
\hline December & 0.0 & 18.9 & 10.3 & 88.2 & 56.7 \\
\hline \multicolumn{6}{|c|}{2002} \\
\hline January & 2.3 & 22.6 & 9.8 & 87.8 & 47.8 \\
\hline February & 9.5 & 26.3 & 13.9 & 87.7 & 49.7 \\
\hline March & 2.3 & 32.5 & 16.6 & 75.5 & 30.0 \\
\hline April & 0.0 & 37.8 & 23.0 & 67.2 & 26.4 \\
\hline May & 10.4 & 38.4 & 26.2 & 65.2 & 39.0 \\
\hline June & 15.3 & 37.3 & 27.4 & 74.5 & 49.7 \\
\hline July & 31.9 & 36.0 & 27.8 & 74.4 & 55.0 \\
\hline August & 76.3 & 32.7 & 26.1 & 87.7 & 69.5 \\
\hline
\end{tabular}


A total of twenty-nine fungal species were isolated from decomposing rice stubble mixed with soil through dilution plate technique (Table 2). For the study of mycoflo$\mathrm{ra}$, the fungi were classified into four groups depending on the frequency, abundance, sporulation and time of appearance in different months.

Table 2. $\mathrm{pH}$, moisture content and average number of fungi per $\mathrm{g}$ of decomposing rice stubble mixed with soil under natural conditions

\begin{tabular}{|l|c|c|c|}
\hline \multicolumn{1}{|c|}{ Months } & $\mathrm{pH}$ & $\begin{array}{c}\text { Moisture content } \\
{[\%]}\end{array}$ & $\begin{array}{c}\text { Average number } \\
\text { of fungi/g oven dry } \\
\text { litter } \times 10^{4}\end{array}$ \\
\hline \multicolumn{3}{|c|}{2001} \\
\hline October & 6.9 & 23.66 & 476800 \\
\hline November & 6.8 & 20.42 & 436800 \\
\hline December & 7.0 & 19.01 & 406600 \\
\hline & 7.1 & 18.88 & 383900 \\
\hline January & 7.2 & 18.32 & 323200 \\
\hline February & 6.9 & 5.55 & 196800 \\
\hline March & 7.0 & 5.35 & 169800 \\
\hline April & 7.1 & 6.02 & 187800 \\
\hline May & 6.8 & 7.44 & 399100 \\
\hline June & 6.8 & 20.22 & 422400 \\
\hline July & 7.0 & 25.32 & \\
\hline August & & & \\
\hline
\end{tabular}

Group I. Dominant fungi: This group included only those, that appeared in more than six observations. The fungi like Rhizopus stolonifer, Aspergillus flavus, A. niger, Trichoderma harzianum, Penicillium citrinum, Alternaria alternata, Cladosporium cladosporioides, Curvularia lunata, Gliocladium sp, Fusarium semitectum and dark sterile mycelium were observed in this group.

Group II. Common fungi: This group consisted of those fungi that appeared in up to six observations with less frequency and abundance. The fungi like Curvularia pallescens, Aspergillus candidus, Penicillium rubrum and Trichoderma viride were recorded in this group.

Group III. Frequent fungi: This group included those fungal species, which were found in up to three or four observations but not more than four. The fungi like Mucor racemosus, Aspergillus sulphuricus, Gliocladium roseum, Phoma glomerata and Nigrospora sphaerica were observed to be the frequent fungi.

Group IV. Rare fungi: Fungi isolated in not more than three observations, were considered as rare. The fungi like Pythium aphanidermatum, Pestalotia mangiferae, Torula graminis, Aspergillus luchuensis, Alternaria solani, N. sphaerica, Drechslera avenacea and Rhizoctonia solani were found in this category. 
The classwise distribution of mycoflora inhabiting decomposing rice stubble in soil is presented in Table 3. The number of fungal species belonging to Oomycetes represented 3.44 per cent of total fungal species, Zygomycetes 10.35 per cent, Ascomycetes 3.44 per cent of total fungal species while members of Deutromycotina represented 75.86 per cent of total fungal population.

Table 3. Classwise distribution of fungi and per cent distribution of various fungal classes of rice stubble mixed with soil under natural conditions

\begin{tabular}{|l|c|c|}
\hline \multicolumn{1}{|c|}{ Classes of fungi } & No. of species isolated & Distribution [\%] \\
\hline Mastigomycotina & 1 & 3.44 \\
Oomycetes & 1 & 6.89 \\
Zygomycotina & 2 & \\
Zygomycetes & 2 & 3.44 \\
Ascomycotina & 1 & 75.86 \\
Deuteromycotina & 22 & 6.90 \\
Coelomycetes & 2 & \\
Sphaeropsidales & 1 & 68.97 \\
Melanconinales & 1 & \\
Hyphomycetes & 20 & \\
Moniliales & 20 & \\
Moniliaceae & 10 & \\
Dematiaceae & 8 & \\
Tuberculariaceae & 2 & \\
\hline Mycelia Sterilia & 3 & \\
\hline Total number of fungi isolated & 29 & \\
\hline
\end{tabular}

\section{DISCUSSION}

The dynamics of fungal community may be attributed generally to abiotic variables and nature of substrate (Khanna 1964; William and Gray 1974, Rai and Srivastava 1982; Thormann et al. 2003). Fungal count and moisture content of stubble mixed in soil had positive correlation with each other. During rainy and winter seasons, temperature and relative humidity were found most favourable for fungal growth and activity. The decline in the number of fungi may be due to several factors such as low moisture content of soil, extremely low or high relative air humidity and wide fluctuation in air temperature during these months. These factors do not favour the sporulation on the substrate (Cruz et al. 2002; Mc Tiernan et al. 2003). The response of soil $\mathrm{pH}$ changes to addition of organic matter depends on the type of plant materials and initial $\mathrm{pH}$ as observed by $\mathrm{Xu}$ and Coventry (2003). The members of phycomycetous and ascomyceteous fungi were noted to be weak colonizers whereas, deutromycetous ones were strong (Table 3 and 4 ). In the present study, initial colonizers were represented by weak colonizers like A. alternata, C. cladosporioides, C. lunata while the saprophytic fungi included species of Mucor, Rhizopus and various species of Aspergillus and Penicillium. Alternaria, Aspergillus, Fusarium, Penicillum, Trichoderma, Mucor, 
Myrothecium and Rhizoctonia were more frequent fungi isolated from Avicennia marina amended than unamended soil (Shaukat et al. 2003). The initial colonization of litter by deuteromycetous fungi highlighted their ability to utilize complex nutrients better than phycomycetous species, which appeared late during the fungal succession. The late appearance of phycomycetous fungi shows their ability to utilize simple compounds either as fungal products or soluble forms. Miller (1974) and Aneja (1988) also observed the dominance of deuteromycetous fungi in the beginning of decomposition process and correlated it with their cellulose utilizing capacity. Valenzuela et al. (2001) reported that Moniliales exhibit the higher enzymatic degradation potential. The order of fungal succession upon a natural substrate reflects the sequential release of different organic and inorganic nutrients, interaction between individual fungi and substratum besides the competition between them (Macauley and Throwes 1966; Singh 2001; Hobbies et al. 2003).

\section{REFERENCES}

Aneja K.R. 1988. Biology of litter decomposition fungi as decomposers of plant litter. p. 389-419 In: "Prospective in Mycology and Plant Pathology" (V.P. Agnihotri, A.K. Sarbhoy, and D. Kumar, eds.). Malhotra Publishing House, New Delhi.

Barnett H.L., Hunter B.B. 1972. Illustrated Genera of Imperfect Fungi. Burges Publishing Co., Minneapolis, Minnesota, USA.

Cruz A.G. Garcia S.S., Rojas F.J.C., Ceballos A.I.O. 2002. Foliage decomposition of velvet bean during seasonal drought. Interciencia 27 (11): 625-630.

Ellis M.B. 1971. More Dematiaceous Hyphomycetes. CMI, Kew, England.

Hobbies E.A., Watrud L.S., Maggard S., Shiroyama T., Rygiewicz P.T. 2003. Carbohydrate use and assimilation by litter and soil fungi assessed by carbon isotopes and BIOLOG (R) assays. Soil Biol. Biochem. 35 (2): 303-311.

Hudson H.J. 1971. Fungal saprophytism. Studies in Biology, No. 32, London, Edward Arnold.

Khanna P.K. 1964. The succession of fungi on some decaying grasses. Ph.D. Thesis, Banaras Hindu University, Varanasi, India.

Macauley V.J., Thrower L.B. 1966. Succession of fungi in leaf litter of Eucalyptus regnans F. Muell. Trans. Brit. Mycol. Soc. 49: 509-520.

Mc Tiernan K.B., Couteaure M.M., Berg B., Berg M.P., de Anta R.C., Kratz A.G.W., Pirussi P., Remacle J., Amalia V.Dc.S. 2003. Changes in chemical composition of Pinus sylvestris needle decomposition along a European coniferous forest climate transect. Soil Biol. Biochem. 35 (6): 801-812.

Miller C.S. 1974. Decomposition of coniferous leaf litter. p. 105-128. In: “Biology of Plant Litter Decomposition" (C.J. Dickinson, C.I.F. Pugh eds.). Academic Press, New York, London.

Nikhra K.M. 1981. Studies on Fungi from Jabalpur Soils with Special Reference to Litter Decomposition. Ph.D. Thesis, Jabalpur University, India.

Rai B., Srivastava A.K. 1982. Decomposition of leaf litter in relation to microbial populations and their activity in tropical dry mixed deciduous forest. Pedobiologia 24: 151-159.

Rai J.P, Sinha A., Govil S.R. 2001. Litter decomposition mycoflora of rice straw. Crop Sci. 21 (3): 335 340.

Saksena S.B. 1955. Ecological factors governing the distribution of micro-soil fungi in forest soil of Sauga. J. Indian Bot. Soc. 34: 262-269. 
Sameni M., Pour A.T. 2001. Effect of root residue of liquorice on different characteristics of soil from southern regions of Iran. I. Microb. Charac. Communic. Soil Sci. and Plant Analys 328 (19/20): 3259-3275.

Shaukat S.S., Siddiqui I.A., Mehdi F.S. 2003. Avicennia marina (mangrove) soil amended changes the fungal community in the rhizosphere and root tissue of mungbean and contributes to control of root knot nematodes. Phytopathologia Mediterranea 42 (2): 135-140.

Singh A. 2001. Studies on Fungal Decomposition of Sunhemp (Crotolaria juncea L.) in Soil. Ph.D. Thesis, B.H.U., Varanasi, India.

Thom C., Raper K.B. 1945. Manual of Aspergilli. Williams and Wilkins Co. Baltimore, USA.

Thorman M.N., Currah R.S., Bayley S.E. 2003. Succession of microfungal assemblages in the decomposing peat land plants. Plant Soil 250 (3): 323-333.

Valenzuela V.P., Leiva S., Godoy R. 2001. Seasonal variation and enzymatic potential of microfungi associated with the decomposition of Northophagous pumilio leaf litter. Rev. Chil Historia Natural 74 (4): 737-749.

Warcup J.H. 1960. Method for isolation and estimation of activity of fungi in soil. In: “Ecology of Soil Fungi" (D. Parkinson, J.S. Waid, eds.). The University Press, Liverpool.

Williams W.T., Gray T.R.G. 1974. Decomposition of the litter on the soil surface. In: "Biology of Plant Litter Decomposition" (C.H. Dickinson, G.J.F. Pugh, eds.). Academic Press, London, New York, $611 \mathrm{pp}$.

Xu R.K., Coventry D.R. 2003. Soil pH changes associated with lupin and wheat plant materials incorporated in a red-brown soil. Plant Soil 250 (1): 113-119.

\section{POLISH SUMMARY}

\section{MIKOFLORA ZWIĄZANA Z ROZKŁADEM ŚCIERNI RYŻU ZMIESZANEJ Z ZIEMIA}

W artykule przedstawiono wyniki izolacji grzybów ze ścierni ryżu zmieszanej z ziemią wykonanych metodą rozcieńczeń płytkowych. Zawartość wilgoci w rozłożonej ścierni wynosiła 25,32\% w sierpniu, natomiast minimalną wilgotność tego substratu wynoszącą 5,25\% stwierdzono w kwietniu, a pH wahała się w granicach 6,8-7,2. Najwyższą liczebność populacji grzybów $(47,68$ x 104) w $1 \mathrm{~g}$ ścierni zmieszanej z ziemią stwierdzono w październiku, a najniższą $\left(16,88 \times 10^{4}\right) \mathrm{w}$ maju. W czasie całego okresu rozkładu ścierni ryżu wykryto 29 gatunków grzybów. Grzyby zaliczone do Deuteromycotina stanowiły 75,86\% całości populacji, natomiast grzyby zaliczone do Zygomycotina, Mastigomycotina i Ascomycotina występowały w odpowiednio zmniejszającym się procencie. Miesięczna zmienność liczebności populacji grzybów była skorelowana z dostępnością substratu oraz z czynnikami klimatycznymi. W toku procesu rozkładu ścierni stwierdzono dominację Rhizopus stolonifer, Aspergillus flavus i Trichoderma harzianum, natomiast grzyby Pestalotia mangiferae, Torula grminis i Alternaria solani były grzybami izolowanymi rzadko. 
